\title{
MACHADO DE ASSIS E A TRADUÇÃO: SINGULARIDADES DA PRÁXIS MACHADIANA EM DIÁLOGO COM OUTROS TRADUTORES
}

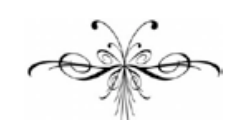

ANA LÚCIA LIMA DA Costa

Resumo: Este artigo se propõe a apresentar um Machado de Assis pouco conhecido: o tradutor. E mais, o teórico da tradução, que muitas vezes antecipou as teorias que a contemporaneidade discute acerca da tradução. Discute-se as contribuições de vários teóricos e praticantes da tradução que de certo modo mantém um diálogo com o pensamento machadiano. O nosso Machado de Assis, em todas as traduções que fez, "se permitiu algumas licenças", as quais demonstram que, para ele, o traduzir não deveria ser um ofício de valor menor que qualquer outro na carreira de um escritor, embora assim continue a ser considerado e, respeitando o original, sem servilismo, exerceu essa atividade durante toda a sua carreira literária contribuindo para tornar-se um exemplo das recentes discussões acerca da teoria da tradução.

Palavras-chave: Tradução; Reescritura; Apropriação; Criação; Machado de Assis.

\begin{abstract}
This article aims to present an almost unknown Machado de Assis, the translator and translation theorist more often anticipated the theories he discusses about the contemporary translation. It discusses the contributions of various theorists and practitioners of translation in a way that maintains a dialogue with the thought Machado. Our Machado de Assis, who made all the translations, "if allowed some licenses", which show that, for him, the result should not be a letter of less value than any other in the career of a writer, though this will continue to be considered and, respecting the original, without servility, this activity has had throughout his literary career by contributing to become an example of the recent discussions about the theory of translation.
\end{abstract}

Keywords: Translation; Rewriting; Appropriation; Creation; Machado de Assis. 


\begin{abstract}
Eu, quando escrevo um livro, vou fazendo como se o estivesse "traduzindo", de algum alto original existente alhures, no mundo astral ou no plano das idéias, dos arquétipos, por exemplo. Nunca sei se estou acertando ou falhando, nessa "tradução". Assim, quando me "re"-traduzem para outro idioma, nunca sei, também, em casos de divergência, se não foi o tradutor quem, de fato, acertou, restabelecendo a verdade do "original ideal”, que eu desvirtuara...
\end{abstract}

Guimarães Rosa

$\mathrm{C}$ omo é impossível trazer neste artigo as manifestações de todos os que se pronunciaram a respeito das teorias de citação, apropriação, reescritura, reinterpretação, ou seja, tudo aquilo que na atualidade é abarcado pelos estudos de tradução, procuramos seguir mais de perto, embora de modo sucinto, o pensamento de alguns intelectuais que de algum modo mantém um diálogo com o pensamento machadiano. Então nos aproximamos da proposta de escritura antropofágica de Oswald de Andrade, consideramos a tarefa do tradutor segundo Walter Benjamin, a transculturação e a plagiotropia de Haroldo de Campos, a tradução-deglutição de Augusto de Campos e a tese do tradutor como autor da diferença de Rosemary Arrojo a fim de entabularmos um diálogo com Machado de Assis para comprovar o quanto esse "escritor de seu tempo e de seu país" antecipa questões tratadas quase um século depois.

Comecemos por 1923, ano no qual Walter Benjamin publica o ensaio "Die Aufgabe des Übersetzers” (“A Tarefa do Tradutor”) em Heidelberg, Alemanha, como prefácio de sua tradução dos Tableaux Parisiens de Baudelaire, que agrupa-se a outros textos em que o autor trabalha com a linguagem como Sobre a Linguagem em Geral e sobre a Linguagem dos Homens (1916); a Doutrina do Semelhante e Sobre a Faculdade Mimética (1933) e Problemas da Sociologia da Linguagem (1935).

Em “A Tarefa do Tradutor”, Benjamin define tradução como "forma”, esclarecendo-a também frente a outras definições negativas: tradução não é recepção, não é comunicação, não é imitação.

Tradução não é recepção, e para comprovar isso Benjamin parte da afirmação de que uma obra de arte ou uma forma de arte ou as reflexões teóricas sobre uma obra de arte não dependem de sua relação com um receptor e que elas apenas implicam “a existência e a essência do homem em geral”. Na verdade, Benjamin já começa seu ensaio afirmando que em lugar algum a importância do receptor revela-se imprescindível para o conhecimento da obra de arte. E que é um “desvio" a concepção de um “receptor ideal”. Assim, pois, como a arte não tem como objetivo um receptor também a tradução não o deve ter, pois que esta tem por finalidade somente traduzir aquela.

De acordo com Benjamin (1987, p. 191) "se ela (a tradução) for destinada ao leitor, também o original o deveria ser. Se o original não existe em função do leitor, como poderíamos compreender a tradução a partir de uma relação dessa espécie?” Esta teoria desencadeou a ira de muitos teóricos, principalmente os da Estética da Recepção, que encerra no leitor/receptor o ponto de partida para suas apreciações artísticas e literárias.

Tradução não é comunicação. Depois de desconsiderar o receptor, Benjamin teoriza que "a arte é muito mais do que comunicação, é comunhão", porque uma obra de arte não comunica o seu essencial, que reside no indizível, 
no "intangível, misterioso, poético". Uma vez que o objetivo da obra de arte não é comunicar, por que o deveria fazer a tradução de tal obra? A comunicação não é essencial também na tradução, e se a pretensão desta for comunicar e servir ao leitor então ela é uma má tradução.

Tradução não é imitação, porque a tarefa do tradutor é "resgatar em sua própria língua a língua pura”, que se complementa na língua estrangeira. É sua tarefa liberar, pela repoetização (Umdichtung), a língua pura, cativa na obra (Dichtung). Desta maneira, o tradutor só pode restituir o poético ao tornar-se ele mesmo um poeta, pois a obra do poeta (Dichter) é fruto do poetizar (dichten). O tradutor (Überzetzer) deve re-poetizar (umdichten) para re-criar aquela obra (Umdichtung), deve tornar-se, pois, re-poetizador (Umdichter). Não pode haver tradução se esta pretende essencialmente imitar o original, diante do que conceitos como fidelidade $\mathrm{X}$ liberdade, suas definições e possibilidades aparecem como secundários, porque ao criar uma obra de arte literária, o poeta já define e imprime um sentido, tornando a tradução isenta do papel de criação deste sentido, já instaurado no original; a tarefa do tradutor não é criar, mas recriar a criação.

Nesse ponto, o ensaísta alemão se aproxima do nosso Machado de Assis que em uma crônica datada de 17 de outubro de 1864 se refere à tradução da Morte de Sócrates assim:

Não li toda a tradução da Morte de Sócrates, nem a comparei ao original; mas as páginas que cheguei a ler pareceram-me dignas do poema de Lamartine. O próprio tradutor declara que empregou imenso cuidado em conservar a frescura original e os toques ligeiros e transparentes do poema. Essa deveria ser, sem dúvida, uma parte da tarefa; para traduzir Lamartine é preciso saber suspirar versos como ele. (ASSIS, In: JACKSON, v.22, p. 192; grifo meu).

A tradução advém do original. A tradução é uma manifestação da vida, “da sobrevida” (Überlen) deste original e enquanto manifestação de vida tem por finalidade a expressão da essência da vida (do original).

Novamente citando Benjamin,

Da mesma forma com que as manifestações vitais estão intimamente ligadas ao ser vivo, sem significarem nada para ele, a tradução provém do original. Na verdade, ela não deriva tanto de sua vida quanto de sua sobrevivência. Pois a tradução é posterior ao original e assinala, no caso de obras importantes, que jamais encontraram à época de sua criação seu tradutor de eleição, o estágio de continuação de sua vida. A idéia da vida e da continuação da vida das obras de arte deve ser entendida em sentido inteiramente objetivo, não metafórico. (Idem, p. 193).

A finalidade da tradução, segundo Benjamin, é a observação da essência, revelada pela língua da verdade, que seria a língua pura, a qual nunca é plenamente resgatada, mas que pode ser concebida a partir da "complementaridade de sentido" possibilitado na reprodução das formas e dos significantes das línguas entre si, e que só pode ser expressa por aproximações e analogias, conseguida pelo poético. "A tarefa do tradutor é provocar o amadurecimento, na tradução, da semente da língua pura”. 
O texto está fundamentado sobre uma concepção de linguagem, uma teoria da linguagem, que Benjamin constrói ao longo de sua obra, na qual os textos vão se interligando, dialogando, se traduzindo. “Tradução é uma forma”. A partir desta tese central, reconceitua a tarefa do tradutor: trans-pôr, transformar na língua da tradução a arte do original, trazendo para a sua língua a maneira de significar do original. A complementaridade surge do confronto entre duas línguas, e possibilita, muitas vezes, a revelação de um sentido antes despercebido na língua do original.

Ou seja, um determinado significado, encoberto nos originais, se demonstra na sua traduzibilidade. Se essa tarefa é possível, a tradução também é possível.

Benjamim também se opõe à tese central da teoria tradicional da tradução que trabalhava sobre a relação entre "fidelidade à palavra e liberdade de reprodução do sentido do original”.

Nesse sentido, assim coloca Benjamin:

Se é a afinidade entre as línguas o que deve se verificar nas traduções, como poderiam elas fazê-lo, senão pela transposição mais exata possível da forma e do sentido do original? Naturalmente, a teoria em questão (teoria tradicional da tradução) não saberia manifestar-se a respeito de como tal exatidão seria concebida e, finalmente, não poderia dar conta daquilo que é essencial em traduções. [...] Para compreender a autêntica relação entre o original e tradução deve-se realizar uma reflexão, cujo propósito é absolutamente análogo ao dos argumentos por meio dos quais a crítica epistemológica precisa comprovar a impossibilidade de uma teoria da imitação. [...] Pode-se comprovar não ser possível existir uma tradução, caso ela, em sua essência última, ambicione alcançar alguma semelhança com 0 original. Pois na continuação de sua vida (que não mereceria tal nome, se não se constituísse em transformação e renovação de tudo aquilo que vive), o original se modifica. (BENJAMIN, p. 195-7; grifos meus) sobre Benjamin

De acordo com Mauri Furlan, especialmente dedicado aos estudos

A tradução possui uma tarefa grandiosa, messiânica, redentora; ela deve, em última instância, expressar a realidade da 'língua pura' que se reflete nas línguas do original e da tradução, da obra de arte e sua 'reprodução'. [...] Seu papel é, como o do profeta, de instrumento, de trans-positor, trans-formador, re-formador, repoetizador da poesia, do modo de significar do original. (FURLAN, 1996, p. 11-2)

Cabe ao tradutor, então, uma missão profética: "reconduzir a linguagem babélica à linguagem edênica”.

Devido à sua ousadia, Die Aufgabe des Übersetzers é um texto que, desde sua publicação, tem motivado inúmeras discussões e mesmo leituras controversas. Um bom exemplo disso é a leitura que Paul de Man faz do ensaio de Benjamin. Ele afirma que "o texto de Benjamin diz que é impossível traduzir" e que "qualquer tradução é sempre inferior em relação ao original, e o tradutor está, como tal, perdido logo à partida”. Já o argentino Jorge Luis Borges discorda e diz que na tradução a recombinação de elementos não é 
obrigatoriamente inferior ao original. A crença na inferioridade das traduções procede da experiência da repetição do original.

Porque para Benjamin

O maior elogio a uma tradução, sobretudo na época de seu aparecimento, não é poder ser lida como um original em sua língua. [...] a verdadeira tradução é transparente, não encobre o original, não o tira da luz; ela faz com que a pura língua, como que fortalecida por seu próprio meio, recaia ainda mais inteiramente sobre o original. (BENJAMIN, 1987, p. 209)

Para Cristina Monteiro de Castro Pereira, em “A Tarefa do Tradutor”, Benjamim se inspira numa passagem bíblica para falar sobre tradução. De acordo com a ensaísta, para Benjamim "a multiplicação dos idiomas afasta os homens de sua origem divina”. Deste modo, a tradução, nos moldes mais tradicionais, estaria contaminada por uma enorme carga de melancolia, "advinda da impossibilidade de recuperação total do texto original em uma outra língua”.

Eis a passagem citada por Pereira

Temendo um novo dilúvio, os homens constroem uma torre de medidas transgressoras: queriam alcançar o céu. A hybris, ancestral tentação trágica do homem de ultrapassar seus limites, está presente na história da Torre de Babel do Antigo Testamento e provoca a ira não mais dos deuses gregos, mas de um onipotente e único Deus. Indignado com a pretensão dos homens, o Todo-Poderoso faz a torre desmoronar e os priva da língua universal: cria e dissemina entre eles diferentes idiomas, dificultando o entendimento entre os povos. (PEREIRA, 2006, p. 1)

Quando lidamos com textos estéticos, cuja significação ultrapassa sua mensagem conteudística e se torna parte de um processo de interação entre o leitor e a obra, torna-se ainda mais difícil abarcar toda a riqueza de significados e transpô-la para uma outra língua.

Diante do impasse e de sentenças taxativas quanto à impossibilidade da tradução de textos literários, chega-se a uma saída possível: assumir a falta e transformá-la em trampolim para a criação. Esta é a solução apontada por teóricos como Haroldo de Campos e Walter Benjamin. O “impossível de se dizer” do original se transforma em espaço para a criação artística. Opondo-se à visão tradicionalista, que colocava o tradutor e seu texto numa posição secundária e subserviente em relação ao autor e ao original, Campos e Benjamin conquistam, para a tradução, sua autonomia.

As lacunas não têm mais, neste caso, uma conotação negativa: a falta que antes provocava melancolia transforma-se agora num impulso criativo para o tradutor.

Como metaforiza Benjamin,

Da mesma forma com que a tangente toca a circunferência de maneira fugidia e em um ponto apenas, sendo esse contato, e não o ponto, que determina a lei segundo a qual ela continua sua via reta para o infinito, a tradução toca fugazmente e apenas no ponto infinitamente pequeno 
do sentido do original, para perseguir, segundo a lei da fidelidade, sua própria via no interior da liberdade do movimento da língua. (BENJAMIN, 1987, p. 211)

Avancemos ao ano de 1928, e atentemos para a Revista de Antropofagia, a qual publica, assinado por Oswald de Andrade 'em Piratininga, ano 374 da deglutição do Bispo Sardinha', a idéia base do "Manifesto Antropófago" (TELES, 1992, p. 353- 60) que traz em si a intenção insidiosa de 'alimentar-se de tudo o que o estrangeiro traz para o Brasil, sugar-lhe todas as idéias e uni-las às brasileiras, realizando assim uma produção artística e cultural rica, criativa, única e própria. Era urgente desvincular-se de laços passados reforça o "Manifesto", que é uma resposta às questões colocadas pela Semana de Arte Moderna de 22 e propõe a renovação da arte brasileira que nasceria da absorção da cultura externa: o europeu devia ser devorado.

Haroldo de Campos crê que com a "antropofagia" oswaldiana, tivemos um sentido mais agudo de pensar o nacional em relacionamento dialógico com o universal. A proposta de Oswald de Andrade é o pensamento de uma devoração crítica do legado cultural universal eliminando a participação do "bom selvagem” romântico, mas através do "mau selvagem” antropófago, devorador daqueles que podem contribuir para o "robustecimento" e a "renovação" de suas próprias forças.

Machado antecipa em muitos de seus textos a proposta oswaldiana. Em Memórias Póstumas de Brás Cubas, especialmente no capítulo do 'delírio', sugere uma devoração próxima da visão antropofágica de Oswald de Andrade que alargou as fronteiras da imitação, adaptação, assimilação e originalidade.

No capítulo em questão, Brás Cubas relata seu próprio delírio e depois de tomar a forma de um barbeiro chinês, de ser transformado na Suma Teológica de S. Tomás, foi restituído à forma humana e arrebatado por um hipopótamo que o levou a origem dos séculos onde dialogou com a Natureza ou Pandora pedindo mais alguns anos de vida:

Para que queres tu mais alguns instantes de vida? Para devorar e seres devorado depois? Não estás farto do espetáculo e da luta? [...] a onça mata o novilho porque o raciocínio da onça é que ela deve viver, e se o novilho é tenro melhor: eis o estatuto universal. (ASSIS, 1992, p. 522).

Desse modo todas as informações advindas de diferentes contribuições, depois de emaranhadas, preparam-se para "nova mastigação”, numa digestão, da qual não é mais possível apontar o "organismo assimilador” (a onça) da “matéria assimilada” (o novilho).

Depois de ser citado várias vezes neste texto, chegou a vez de nos atermos mais detidamente em Haroldo de Campos, poeta, crítico e tradutor, cuja ação regula-se pela conjugação da tradução com a antropofagia, decorrente da associação com a intertextualidade. Por esse caminho, "retoma-se o projeto artístico modernista de Oswald de Andrade e se recoloca a questão da nossa literatura e das literaturas do chamado Terceiro Mundo como 'tradutoras' da cultura do Outro" (SOUZA, 1993, p. 39). A necessidade de congregar a produção artística dentro de um movimento universal provoca a conscientização da nossa dívida para com as culturas dominantes, mas, por outro lado, insinua que a superação desse débito se dá por meio da devoração antropofágica da 
herança cultural estrangeira e a devolução de um texto modificado por uma digestão oswaldiana que torna impossível distinguir o assimilador do assimilado.

De seu artigo "Da razão antropofágica: A Europa sob o signo da devoração”, de 1981, originalmente publicado na Revista Colóquio/Letras, Lisboa, podemos destacar a opinião de Campos com relação a essa prática:

A um certo momento, com Borges pelo menos, o europeu descobriu que não podia mais escrever a sua prosa do mundo sem o contributo cada vez mais avassalador da diferença aportada pelos vorazes bárbaros alexandrinos. Os livros que lia já não podiam ser os mesmos, depois de manducados e digeridos pelo cego homeríada de Buenos Aires, que ousara até mesmo reescrever o Quijote, sob o pseudônimo de Pierre Menard... Que haveria de novo, sem Borges, no nouveau roman de Robbe-Grillet? Quem poderá agora ler Proust sem admitir Lezama Lima? Ler Mallarmé, hoje, sem considerar as hipóteses intertextuais de Trilce de Vallejo e Blanco de Octavio Paz? (CAMPOS, 1991, p. 23)

A opinião generalizada veicula que traduzir é trair, mas para Haroldo de Campos é uma traição que gera virtudes. Desafiando as reservas contra a tradução, ele praticou-a durante anos, sistematicamente. Porém, ao contrário de muitos, raramente traduziu obras inteiras, apenas o que lhe agradava e acreditava que traduzir é transcriar.

Transcriação é um neologismo cunhado por Haroldo de Campos para nomear um tipo de tradução que ultrapassa os limites do significado e se propõe a fazer funcionar o próprio processo de significação original numa outra língua. Essa proposta retoma criativamente o "modo de intencionar" do original e o recria de modo artístico, através de sutilezas da forma e da linguagem em português. Mas isto ocorre de tal forma que acaba por tornar-se o que o escritor brasileiro chama de "transluciferação mefistofáustica".

O texto “Transluciferação Mefistofáustica” está presente no livro Deus e o Diabo no Fausto de Goethe (1981), no qual Haroldo de Campos comenta o seu método de trabalho a respeito de sua tradução da segunda parte do Fausto. Já a partir do título do livro podemos observar o processo de criação de Campos, qual faz referência ao filme de Glauber Rocha, Deus e o Diabo na Terra do Sol (1963) e a um clássico do Romantismo Alemão. A justaposição dos títulos do filme e do romance na composição do título da obra de Campos remete à aproximação de uma obra artística oriunda de um contexto periférico irreverentemente associada a um romance canônico.

Já o termo "transluciferação mefistofáustica” deve ser olhado também através do processo de composição e também representa o viés da teorização tradutória de Haroldo de Campos. A palavra "transluciferação" é formada pelo prefixo "trans-" que significa "movimento através de" e pelo vocábulo "luciferação" que por sua vez é derivado da colocação de um sufixo à palavra Lúcifer, expressando que a tradução se dá através de um processo e de uma atitude luciferina. Nesse ponto, Campos se afasta da teoria de Benjamin que apresenta uma concepção angelical, segundo a qual a tradução "libera a língua pura cativa no original”. A segunda palavra do termo retoma dois personagens do Fausto, de Goethe: Fausto e Mefistófeles. O primeiro é um velho cientista que se sente insatisfeito com o que realizou, já que pensa ter sacrificado sua 
juventude, além de nunca ter encontrado um grande amor. Diante disso, o segundo, oferece a ele a mocidade perdida, dinheiro e o amor de uma mulher. Em troca, Fausto teria que lhe oferecer sua alma. Numa relação simbólica Mefistófeles seria a tradução, possuidora de um poder luciferino, satânico e Fausto, o original, que num pacto com a tradução se doaria, mas receberia de volta a própria vida renovada. De acordo com alguns estudiosos, até o posicionamento dos termos na palavra "mefistofáustico" parece sugerir que é a tradução é que deve se mover em direção ao original, na intenção de, num pacto, oferecer-lhe nutrimento em troca da sua forma, pois o termo Mefisto vem antecedendo Fausto.

De modo muito semelhante a Machado de Assis, Haroldo de Campos vai embutindo sua teoria em toda sua produção literária, diretamente ou através de metáforas, como a definição da tradução "como transfusão. De sangue. Com um dente de ironia poderíamos falar em vampirização, pensando agora no nutrimento do tradutor" (CAMPOS, 1981, p. 208).

Segundo Campos, o discurso tanto musical quanto literário, possui um elemento que pode ser imitado, variado, transposto, modulado, por vezes transformado até se tornar irreconhecível... "um outro de si mesmo" que caminha simplesmente para se tornar um novo ente, verdadeiramente autônomo no seu significado estético.

Atualmente parece haver um consenso de que o ato de tradução exige do tradutor uma prática criativa e crítica capaz de recriar o texto original de modo a respeitar-lhe a integridade estética.

O discurso tradutório torna-se relevante por propiciar uma abertura efetiva dos escritores e leitores para a compreensão de que o contato com outras culturas seria positivo e contribui para a criação universal, além de afirmar que

Escrever, hoje, na América Latina como na Europa, significará, cada
vez mais, reescrever, remastigar. Os vândalos, há muito, já cruzaram as
fronteiras e tumultuavam o senado e agora, como prenunciado no
poema de Kaváfis. Que os escritores logocêntricos, que se imaginavam
usufrutuários privilegiados de uma orgulhosa koiné de mão única,
preparem-se para a tarefa cada vez mais urgente de reconhecer e
redevorar o tutano diferencial dos novos bárbaros da politópica e
polifônica civilização planetária. Afinal não custa repensar a
advertência atualíssima do velho Goethe: “Eine jede Literatur ennuyiert
sichzuletzt in sich selbst, wenn sie nicht durch fremde Teilnahme
wieder aufgefrischt wird” (Toda literatura, fechada em si mesma, acaba
por definhar no tédio, se não se deixa, renovadamente, vivificar por
meio da contribuição estrangeira). (CAMPOS, 1981, p. 23-4)

Na opinião de Campos, o grande tradutor do século XX foi Ezra Pound, pois somente a postura resultante do lema Make it new (Transforme-o em novo) permite ao tradutor "ser fiel ao espírito, ao clima particular da peça traduzida” (CAMPOS, 2006, p. 37) e, ao mesmo tempo “acrescentar-lhe, como numa contínua sedimentação de estratos criativos, efeitos novos ou variantes, que o original autoriza em sua linha de invenção”. (Idem, p. 35). Dentro do universo tradutório poético inglês é indiscutível a importância de Ezra Pound e é inegável a sua influência na constituição do pensamento teórico e de tradução dos irmãos Campos. 


\section{Como lembra Haroldo de Campos:}

Para nós, tradução de textos criativos será sempre recriação, ou criação paralela, autônoma, porém recíproca. Quanto mais inçado de dificuldades esse texto, mais recriável, mais sedutor enquanto possibilidade aberta de recriação. Numa tradução dessa natureza, não se traduz apenas o significado, traduz-se o próprio signo, ou seja, sua fisicalidade, sua materialidade mesma. O significado, o parâmetro semântico, será apenas e tão-somente a baliza demarcatória do lugar da empresa recriadora. Está-se pois, no avesso da chamada tradução literal. (CAMPOS, 1997, p. 35)

O transcriador, para muito além de nos proporcionar o texto traduzido, visa transformar o passado em algo novo: "todo o passado que nos é outro merece ser devorado. Vale dizer: merece ser comido, devorado” (CAMPOS, 1991, p. 23) e isso também é uma forma de seletividade à moda antropofágica — assimilar o que convém.

Assim diz Campos com relação à Machado de Assis que para ele era um grande devorador:

O grande e inclassificável Machado, deglutidor de Laurence Sterne e de incontáveis outros (é dele a metáfora da cabeça com 'um bucho de ruminante'), onde, como lembra Augusto Meyer num atilado estudo de fontes, "todas as sugestões, depois de misturadas e trituradas, preparam-se para nova mastigação, complicado quimismo em que já não é possível distinguir o organismo assimilador das matérias assimiladas”. (CAMPOS, 1981, p. 13)

Já o conceito de plagiotropia formulado por Haroldo de Campos confirma a "reproposição do passado através de várias etapas de sincronia, ao longo da história, de uma memória não linear, mas muitas vezes oblíqua ou deformada” (CAMPOS, 1976, p. 62). Seria uma tradução da tradição numa proposta de re-apresentação transformadora que em vez de destruir o original prolongaria sua vida através da nova apresentação. Nessa tarefa, a voz do tradutor antes afônica ganha timbre novo e autonomia dentro do texto em oposição a uma tentativa de transparência frustrada porque nunca conseguida.

O nosso Machado de Assis, em todas as traduções que fez, "se permitiu algumas licenças”, as quais demonstram que, para ele, o traduzir não deveria ser um ofício de menor valor que qualquer outro na carreira de um escritor, embora assim continue a ser considerado e, respeitando o original, sem servilismo, exerceu essa atividade durante toda a sua carreira literária contribuindo para tornar-se um exemplo da teoria da plagiotropia mais tarde defendida por Campos.

Aproximando-se ou afastando-se do original, tanto Campos como Machado não abrem mão do diálogo: é a partir dele que fazem suas escolhas, recriando o passado mas não negando uma ruptura com a origem.

De acordo com Esteves,

Se Haroldo de Campos tem razão, a maior criação que Machado de Assis legou para a estética do nosso romance foi o seu capítulo. Segundo o autor, a originalidade do capítulo machadiano reside 
justamente em sua tartamudez, que se constitui numa forma de dizer o outro e de dizer outra coisa abrindo lacunas [...] por onde se insinua o distanciamento irônico da diferença. (ESTEVES, 1996, p. 150)

Para um outro Campos, Augusto, a tradução mostra-se essencial porque é um desafio, um prazer, um modo de conversar com os poetas que ele mais admira, uma crítica do fazer poético e uma disciplina do Ego. Através dessa justificativa do fazer tradutório percebemos uma desmistificação da concepção da tradução como simples repetição do "original”. Para ele, a tradução é uma forma de aprendizado e é ainda, nas palavras do próprio Augusto de Campos,

Uma forma de devolver à coletividade os conhecimentos que adquiri, tornando acessíveis realizações afastadas do convívio da maioria, pelo idioma e pela dificuldade do texto, mas a meu ver constituem alimento básico para a renovação da experiência humana (CAMPOS, 1982, p. 94).

Nesse sentido, a tradução para Augusto de Campos propõe um olhar crítico sobre o texto estrangeiro para que sua versão para a língua materna supere a ideia de cópia e venha a se tornar um produto que traga algo de acréscimo. E esse aspecto não norteia apenas a teoria proposta por Campos, como também a sua prática.

Um de seus argumentos teórico-tradutórios está expresso em citações como esta:

Tradução para mim é persona. Quase heterônimo. Entrar dentro da pele do fingidor para refingir tudo de novo, dor por dor, som por som, cor por cor. Por isso nunca me propus a traduzir tudo. Só aquilo que minto. Ou que minto que sinto, como diria, ainda uma vez, Pessoa em sua própria persona (CAMPOS, 1988, p. 7).

Augusto de Campos se apropria de Fernando Pessoa para relacioná-lo à tradução, criando, por exemplo o neologismo "refingir" e fazendo alusão à dor "que deveras sente". Retomando uma de suas justificativas para se praticar a tradução - um modo de conversar com os poetas que ele mais admira - Augusto de Campos se refere ao modo de se aproximar dos poetas que ama e traduz desta maneira: “A minha maneira de amá-los é traduzi-los. Ou degluti-los, segundo a Lei Antropofágica de Oswald de Andrade: só me interessa o que não é meu.” (CAMPOS, 1988, p. 7).

Partindo da concepção do tradutor como autor da diferença, encontramos Rosemary Arrojo, que toma uma posição frente à tradução que é contrária àquela que mantém os clichês tradicionais, que sempre empobreceram e limitaram qualquer reflexão ou discussão teórica sobre a tradução. A teórica faz reflexões sobre a tradução, levantando questões sobre a relação entre a linguagem humana e o ser humano de maneira inovadora. Ao afirmar que o papel do tradutor é o de produtor e transformador de significados, reafirma sua posição defendida em Oficina de Tradução - Teoria na Prática (1986), O Signo Desconstruído - Implicações para a Tradução, a Leitura e o Ensino (1992) e Tradução, Desconstrução e Psicanálise (1993). Nesses e em outros textos, não só valoriza a tradução enquanto prática, como ilustra e reafirma a teoria de 
Jacques Derrida de que um texto original está em débito com a tradução, ou seja: “a tradução é uma forma de escritura produtiva exigida pelo original”. Não só junto a esta postura da tradução/escritura, a autora aborda também a tradução como uma atividade profissional na qual o tradutor tem um papel decisivo na produção de significados. Partindo desta proposta, Arrojo denomina todo o seu empreendimento teórico de pós-estruturalista.

Segundo Rosemary Arrojo, a leitura e o ensino:

Qualquer tradução, por mais simples e despretensiosa que seja, traz consigo as marcas de sua realização: o tempo, a história, as circunstâncias, os objetivos e a perspectiva de seu realizador. Qualquer tradução denuncia sua origem numa interpretação, ainda que seu realizador não a assuma como tal. Nenhuma tradução será, portanto, 'neutra' ou 'literal', será sempre e inescapavelmente, uma leitura.

(ARROJO, 1993, p. 78)

A mesma Rosemary Arrojo, em seu texto "A que são fiéis tradutores e críticos de tradução?” (ARROJO, 1993, p. 15-26) discute resenha publicada na Folha de S. Paulo em 1985 e assinada por Nelson Ascher sobre John Donne que agora citaremos para ilustrar, de certa maneira, os comentários que aqui fazemos sobre tradução. Em sua resenha, diz Arrojo, Ascher inicia os comentários sobre as traduções de Paulo Vizioli, tomando como paralelo as traduções do poeta e ensaísta Augusto de Campos. Depois de réplicas e tréplicas, em meio a afirmações de que a tradução de Vizioli é "útil e muito necessária”, porém "conservadora e com uma diç̧ão poética ultrapassada” e a de Augusto de Campos é "obra criativa” e que criou para Donne uma "linguagem própria e uma dicção poética condizente”, descobrimos que o critério que leva Ascher a considerar "um lance realmente inventivo" de Augusto de Campos é a incorporação de um verso de Lupicínio Rodrigues ao poema "A Aparição". Ao afirmar que o que distingue "de fato" as duas traduções é “a concepção de tradução que as norteia”, continua Arrojo, Ascher parece estar se referindo às duas concepções opostas de tradução tradicionalmente citadas: uma, atribuída a Vizioli, é a tradução "literal”, que "se contenta com uma linguagem conservadora e com uma dicção poeticamente ultrapassada", "valioso subsídio para o estudo e a apreciação do autor, correta e esclarecedora"; a outra, atribuída a Augusto de Campos, é a tradução supostamente "criativa”, com "lances inventivos”. Ele, por sua vez, acredita que os textos de um poeta do passado só terão valor numa tradução se puderem ser “absorvidos” por poetas do presente. Ao acreditarmos que existe um "outro" autor permeando e permeado no texto traduzido, desmistificamos a ingenuidade da tradução bem-intencionada que se esforça pela fidelidade cega ao original. A visibilidade do tradutor como autor da diferença e da possibilidade de sobrevivência do modelo também torna visível o anseio de captação e de assimilação implícito em qualquer ato tradutório.

Se esse encontro acontece dentro de uma rede de fascínio e adoração, dá-se também a partir de uma ação de devoração e combate. Deste modo, o contato com o texto sempre submerge um anseio de ter um conhecimento que se atribui inicialmente ao outro e é, a partir dessa vontade, que surgem não apenas a leitura e a tradução, mas também, a escritura. 
Voltando ao texto de Rosemary Arrojo, “A tradução e o flagrante da transferência” (ARROJO, 1993, p. 151-176), onde a crítica discute "algumas aventuras textuais com Dom Quixote e Pierre Menard”, encontramos a mesma discussão em torno da escritura. Afirma a autora que

Se a escritura tem sua origem numa leitura, ou seja, no desejo de também ocupar o lugar autoral daquele que considero um "sujeito suposto saber”, a leitura já se realiza sob o signo de um desejo de apropriação. Se não há textos, mas apenas relações entre textos, a relação de influência, nos termos descritos por Harold Bloom, "governa a leitura da mesma forma que governa a escritura, e a leitura é, portanto, uma desescritura da mesma forma que a escritura é uma desleitura”.(ARROJO, 1993, p. 161-2)

Pelo que retomamos aqui, conclui-se que já no século XIX, o crítico Machado antecipou questões com as quais hoje se deparam diversos críticos no estudo da tradução, e nesse momento, que é o da discussão sobre esse fenômeno literário que é a tradução, muito pouco se tem alertado para a lacuna que se instaura nos estudos machadianos pela não-discussão da prática tradutória exercida por ele. Ledo Ivo ressalta a falta de interesse dos críticos de Machado por sua "práxis tradutória":

As atividades de Machado de Assis como tradutor não têm sido esmiuçadas pelos seus críticos e biógrafos, que se agarram ao exemplo da tradução de "O Corvo", de Edgar Allan Poe, contentando-se com esse episódio afortunado e fazendo apenas menções sumárias à parte quase total do ofício. Registra Lúcia Miguel Pereira que ele traduziu, entre 1860 e 1867, nada menos que sete peças teatrais, inclusive $\mathrm{O}$ Barbeiro de Sevilha, de Beaumarchais, e o romance Os Trabalhadores do Mar, de Victor Hugo. Não são, porém, estabelecidos os vínculos entre autor e tradutor, como se não tivesse havido entre ambos qualquer comunicação ou proveito (IVO, 1976, p. 51).

Raros ensaios são publicados sobre o assunto e apenas Eliane Ferreira (1998) tem um trabalho de maior fôlego sobre o tema e aborda as traduções machadianas para a ribalta. Segundo a estudiosa, Machado de Assis traduziu textos, abrangendo poesia, romance, teatro, ensaio. Principalmente teatro e poesia. Eliane aponta que Machado também opinava sobre as traduções de peças como parecerista do Conservatório Dramático Brasileiro. De acordo com ela, o velho bruxo afirmava que "o tradutor dramático é uma espécie de criado de servir que passa, de uma sala a outra, os pratos de uma cozinha estranha”.

O que podemos perceber escavando os labirintos da práxis machadiana é que o autor oitocentista iniciou seu trabalho como tradutor e parecerista de tradução e enquanto exercia essas tarefas acreditava numa tradução muito semelhante ao "original”. Avançando no labirinto, conduzidos pelo fio de Ariadne, descobrimos um Machado de Assis que embutiu em seus ensaios e mesmo nos textos literários um olhar diverso sobre a tradução: aquela que faz reviver o texto "original” em outra roupagem, seja esta por força do tempo ou do contexto para o qual esse segundo texto, o traduzido, for oferecido.

Cabe a nós, seguindo o fio condutor, chegar ao centro deste labirinto, o da tradução, e desvendar mais uma faceta do bruxo do Cosme Velho. 
Ana Lúcia Lima da Costa

analucialetras@ig.com.br

Universidade Federal Fluminense

\section{Referências}

ARROJO, Rosemary. Tradução, Desconstrução e Psicanálise. Rio de Janeiro: Imago, 1993.

BENJAMIN, Walter. A Tarefa do Tradutor. Trad. Sérgio Paulo Rouanet. São Paulo: Brasiliense, 1987.

CAMPOS, Augusto . Poesia, Antipoesia, Antropofagia. São Paulo: Cortez \& Moraes, 1982.

Verso, Reverso, Controverso. São Paulo: Perspectiva, 1988.

CAMPOS, Haroldo. de . Da tradução como Criação e como Crítica. Metalinguagem. São Paulo: Cultrix, 1976. p. 62-70 . Da razão antropofágica: A Europa sob o signo da devoração. In: Colóquio/ Letras 62. Julho de 1991, pp. 10-25.

. O arco-íris branco: ensaios de literatura e cultura. Rio de Janeiro: Imago, 1997.

Deus e o Diabo no Fausto de Goethe. São Paulo: Perspectiva, 1981

Metalinguagem \& outras metas. São Paulo: Perspectiva, 2006.

ESTEVES, Paulo. O Conselheiro Aires e a Crônica Mundana de Machado de Assis. Belo Horizonte: Vária História, nº 15, 1996, p. 133-154.

FERREIRA, Eliane Fernanda Cunha. Machado de Assis sob as luzes da ribalta. São Paulo: Cone Sul, 1998.

FURLAN, Mauri. Possibilidade(s) de Tradução(ções). In: Cadernos de Tradução. No III. Florianópolis: NUT, 1996. p. 89 a 111

IVO. Ledo. Teoria e Celebração: ensaios. São Paulo: Duas Cidades, 1976.

MACHADO DE ASSIS, Joaquim Maria. Obra Completa. Vols. I, II e III. Rio de Janeiro: Aguilar, 1992 Crônicas. Rio de Janeiro: Jackson, 1952, v.22.

PEREIRA, Cristina Monteiro de Castro. Transcriação: a tradução em jogo. In: Cadernos do CNLF, série VIII, n.06. Rio de Janeiro: CIFEFIL, 2004. Disponível em: <http://www.filologia.org.br/viiicnlf/anais/caderno0615.html>. Acesso em 08 março 2007.

SOUZA, Eneida Maria de. Tradução e intertextualidade. In: Traço Crítico. Belo Horizonte: Editora da UFMG/Rio de Janeiro: Editora da UFRJ, 1993. p. 34 a 47

TELES, Gilberto Mendonça. Vanguarda Européia e Modernismo Brasileiro: apresentação dos principais poemas, manifestos, prefácios e conferências vanguardistas, 1857 a 1972. Petrópolis, RJ: Vozes, 1997. 